\title{
PEMANFATAN SISTEM INFORMASI GEOGRAFIS (SIG) UNTUK PEMETAAN IMBUHAN AIRTANAH DAN KERENTANAN AIRTANAH DI KAWASAN KARST (STUDI KASUS DI KECAMATAN PALIYAN DAN KECAMATAN SAPTOSARI, KABUPATEN GUNUNGKIDUL)
}

\author{
Ahmad Cahyadi ${ }^{1,3}$ dan Fedhi Astuty Hartoyo ${ }^{2,3}$ \\ ${ }^{1}$ Mahasiswa Jurusan Geografi Lingkungan, Fakultas Geografi UGM Yogyakarta \\ ahya.edelweiss@gmail.com \\ ${ }^{2}$ Mahasiswa Jurusan Sains Informasi Geografi dan Pengembangan Wilayah, Fakultas Geografi UGM \\ ${ }^{3}$ Anggota Karst Student Forum (KSF) Fakultas Geografi UGM Yogyakarta
}

\begin{abstract}
ABSTRAK
Pemetaan imbuhan airtanah dan kerentanan airtanah merupakan bagian yang penting dalam upaya pengelolaan kawasan karst. Penelitian ini dilakukan di sebagian Kawasan Karst Gunungsewu di Kecamatan Paliyan dan Kecamatan Saptosari, Kabupaten Gunungkidul. Penelitian ini bertujuan untuk mengetahui sebaran spasial tingkat imbuhan airtanah dan tingkat kerentanan pencemaran airtanah. Metode yang digunakan dalam penelitian ini adalah APLIS yang memanfaatkan sistem informasi geografis (SIG) dengan analisis tumpangsusun (overlay). Variabel yang digunakan dalam penelitian ini adalah ketinggian tempat (elevasi) dari permukaan laut, kemiringan lereng, litologi (batuan), zona infiltrasi, dan tanah. Hasil penelitian menunjukkan bahwa nilai imbuhan airtanah dan tingkat kerentanan airtanah meliputi tingkat sangat rendah sampai dengan tinggi.
\end{abstract}

Kata Kunci: Imbuhan airtanah, kerentanan airtanah, karst, sistem informasi geografis (SIG), APLIS

\section{PENDAHULUAN}

\subsection{Latar Belakang}

Keputusan Menteri Energi dan Sumber Daya Mineral Nomor $1456 \mathrm{~K} / 20 / \mathrm{MEM} / 2000$ tentang pengelolaan kawasan karst sebagai satu-satunya aturan hukum di Indonesia yang mengatur tentang pengelolaan kawasan karst mewajibkan dilakukannya zonasi kawasan karst dalam upaya pengelolaan kawasan karst. Pengelolaan kawasan karst diartikan sebagai kegiatan yang meliputi inventarisasi, penyelidikan, pemanfaatan, dan perlindungan sumberdaya pada kawasan karst (Keputusan Menteri Energi dan Sumber Daya Mineral Nomor 1456 K/20/MEM/2000 tentang pengelolaan kawasan karst). Fungsi utama dari pengelolaan kawasan karst adalah untuk mengoptimalkan pemanfaatan kawasan karst guna menunjang pembangunan yang berkelanjutan dan berwawasan lingkungan.

Zonasi kawasan karst akan menghasilkan suatu peta tentang klasifikasi wilayah dalam tiga kelompok yakni kawasan karst kelas I, II dan III. Berikut ini adalah penjelasan kriteria klasifikasi menurut Keputusan Menteri Energi dan Sumber Daya Mineral Nomor 1456 K/20/MEM/2000 tentang pengelolaan kawasan karst:

a. Kawasan Karst kelas I

Kawasan karst kelas I meliputi kawasan karst yang memiliki salah satu fungsi dari beberapa hal berikut:

1) Kawasan yang berfungsi sebagai kawasan penyimpan air secara tetap dalam bentuk akuifer, sungai bawah tanah, telaga, atau danau bawah tanah;

2) Kawasan yang memiliki gua-gua dan sungaisungai bawah tanah yang aktif yang membentuk jaringan baik secara horisontal ataupun vertikal;

3) Kawasan yang memiliki gua-gua dengan speleothem (ornamen-ornamen gua) yang aktif atau peninggalan sejarah sehingga berpotensi dikembangkan sebagai objek wisata; atau

4) Kawasan yang memiliki flora dan fauna khas yang memenuhi arti dan fungsi sosial, ekonomi, budaya serta pengembangan ilmu pengetahuan.

b. Kawasan Karst Kelas II

Kawasan karst kelas II adalah kawasan karst yang tidak memiliki kriteria yang disebutkan dalam kawasan karst kelas I namun memiliki salah satu dari kriteria berikut ini:

1) Kawasan yang berfungsi sebagai pengimbuh air bawah tanah berupa daerah tangkapan air hujan yang mempengaruhi naik turunnya permukaan air bawah tanah kawasan karst sehingga secara umum masih mendukung fungsi hidrologis kawasan karst; atau

2) Kawasan yang berfungsi sebagai jaringan lorong-lorong bawah tanah hasil bentukan sungai dan gua yang sudah kering, serta menjadi tempat tinggal yang tetap bagi fauna yang semuanya dapat memberi nilai dan manfaat ekonomi. 


\section{c. Kawasan Karst Kelas III}

Kawasan karst kelas III adalah kawasan yang tidak memiliki kriteria sebagaimana yang disebutkan dalam kawasan karst kelas I dan II.

Salah satu langkah yang penting dalam melakukan zonasi kawasan karst adalah pemetaan imbuhan airtanah dan pemetaan kerentanan airtanah. Wilayah yang merupakan daerah potensial imbuhan airtanah kawasan karst harus dilindungi. Hal tersebut berlaku juga untuk daerah dengan tingkat kerentanan airtanah yang tinggi. Hal ini agar sumberdaya air di kawasan karst dapat dijaga secara kuantitas ataupun kualitasnya.

Kawasan Karst Gunungsewu merupakan salah satu kawasan karst yang sangat unik di Indonesia. Hal ini terbukti dari diterimanya penghargaan dari Asia-pasific Forum on Karst Ecosystems and World Heritage sebagai World Natural Heritage. Oleh karena itu, penelitian mengenai pemetaan wilayah imbuhan dan sebaran tingkat kerentanan airtanah menjadi sangat penting dilakukan untuk mendukung pembuatan rencana pengelolaan kawasan karst Gunungsewu dimasa mendatang.

\subsection{Tujuan Penelitian}

Tujuan penelitian ini adalah untuk mengetahui sebaran spasial tingkat imbuhan airtanah dan tingkat kerentanan pencemaran airtanah pada lokasi penelitian.

\section{TINJAUAN PUSTAKA}

\subsection{Karst}

Karst adalah bentuklahan yang secara dominan terbentuk akibat pelarutan batuan (Veni dan DuChene, 2001). Ford dan Williams (1992) mendifinisikan karst sebagai medan dengan karakteristik hidrologi dan bentuklahan yang diakibatkan oleh kombinasi batuan yang mudah larut dan mempunyai porositas sekunder yang berkembang dengan baik. Worosuprojo (1997) secara lebih jelas menjelaskan bahwa kawasan karst dapat terbentuk apabila terpenuhi beberapa syarat sebagai berikut:

a. Terdapat batuan yang mudah larut, kompak, tebal dan mempunyai banyak retakan. Batuan yang mudah larut dapat berupa gamping, dolomit dan gipsum. Semakin tinggi kemurnian batuannya, maka proses pelarutan akan semakin baik.

b. Memiliki curah hujan yang cukup tinggi. Faktor curah hujan menjadi sangat penting karena hujan merupakan media pelarut dalam proses karstifikasi. Oleh karena itu, maka semakin tinggi curah hujan maka proses pelarutan akan semakin intensif.

c. Batuan yang mudah larut terangkat di ketinggian yang memungkinkan perkembangan sirkulasi atau drainase secara vertikal. Syarat ini penting ada agar terjadi jarak yang cukup antara batuan gamping yang tidak jenuh air dengan muka airtanah, sehingga mampu terbentuk drainase air secara vertikal. Hal ini berarti bahwa semakin tinggi batuan karbonat terangkat, maka proses karstifikasi akan semakin intensif.

\subsection{Airtanah}

Airtanah adalah air yang berada pada wilayah jenuh di bawah permukaan tanah (Asdak, 2007). Airtanah di kawasan karst sangat dipengaruhi oleh keberadaan porositas sekunder. Infiltrasi yang terjadi terjadi melalui peresapan pada rongga antar butir dan lebih dominan melalui kekar, retakan dan celahcelah batuan yang terjadi akibat pelarutan.

\subsection{Imbuhan Airtanah}

Andreo dkk (2004) menyatakan bahwa imbuhan airtanah adalah sejumlah air hujan yang masuk ke dalam sistem akuifer selama periode tertentu, meskipun tidak menutup kemungkinan imbuhan airtanah berasal dari air permukaan. Lubis (2006) menyebutkan bahwa wilayah imbuhan airtanah atau sering juga disebut dengan daerah resapan air adalah wilayah yang mampu meresapkan air, kemudian mampu mengalirkannya sampai zona jenuh air. Karakteristik yang berbeda antara satu tempat dengan tempat yang lain menyebabkan setiap tempat memiliki kemampuan meresapkan air berbeda-beda.

\subsection{Kerentanan Airtanah}

Vrba dan Zaporozec (1994) mengatakan bahwa pemetaan kerentanan airtanah (groundwater vulnerability) merupakan bagian dari upaya perlindungan kualitas airtanah yang diperkenalkan pertama kali oleh ahli hidrologi Perancis, Margat pada tahun 1960. Margat mendefinisikan kerentanan airtanah sebagai kemungkinan terjadinya suatu pencemaran atau kontaminasi bahan pencemar pada suatu akuifer di suatu wilayah. Pengertian tersebut hampir sama dengan apa yang dikemukakan oleh Harter dan Walker (2001) yang menjelaskan bahwa kerentanan airtanah adalah ukuran tingkat kemudahan atau tingkat kesulitan suatu polutan dapat mencemari airtanah di suatu wilayah.

Vrba dan Zaporozec (1994) membagi kerentanan airtanah menjadi dua, yaitu kerentanan airtanah alami dan kerentanan airtanah gabungan. Kerentanan airtanah alami adalah tingkat kerentanan airtanah yang ditinjau berdasarkan karakteristik hidrogeologi, sedangkan kerentanan airtanah gabungan adalah kerentanan airtanah yang dinilai berdasarkan faktor hidrogeologi dan dampak faktor aktivitas manusia yang mampu menyebabkan penurunan kualitas airtanah di suatu wilayah. Klasifikasi yang hampir sama dikemukakan oleh Leibundgut (1998 dalam Adji, 2006) yang membagi kerentanan airtanah menjadi kerentanan airtanah intrinsik dan kerentanan airtanah spesifik. Kerentanan airtanah intrinsik adalah kerentanan yang didasarkan pada karakteristik dan sifat 
hidrogeologi dan geomorfologi suatu wilayah, sedangkan kerentanan airtanah spesifik adalah tingkat kerentanan akibat ancaman aktual yang ada di suatu wilayah seperti limbah domestik dan penggunaan lahan.

\section{METODE PENELITIAN}

Metode yang digunakan dalam penelitian ini adalah metode APLIS. Andreo, dkk (2008) menjelaskan bahwa metode ini menggunakan lima variabel yang didasarkan pada karakteristik hidrogeologi dan geomorfologi suatu wilayah. Oleh karena itu, maka metode ini hanya dapat digunakan untuk menentukan kerentanan airtanah intrinsik dari suatu wilayah.

APLIS merupakan singkatan dari lima variabel yang digunakan dalam Bahasa Spanyol. Lima variabel yang digunakan dalam metode APLIS meliputi; altitud (ketinggian), pendiente (kemiringan lereng), litologia (litologi), infiltraction preferencial (zona infiltrasi), dan suelo (tanah). Masing-masing variabel dikelaskan dan diberi skor sesuai dengan tingkat pengaruhnya terhadap besarnya imbuhan airtanah yang kemudian akan mencerminkan tingkat kerentanan airtanah di suatu wilayah pula. Berikut ini klasifikasi yang digunakan untuk masing-masing variabel berdasarkan pada penelitian yang dilakukan oleh Andreo, dkk (2008):

Tabel 1. Klasifikasi dan skoring variabel litologi

\begin{tabular}{|l|l|}
\hline \multicolumn{1}{|c|}{ Litologi/ Batuan } & \multicolumn{1}{c|}{ Skor } \\
\hline $\begin{array}{l}\text { Batu gamping dan dolomit terkarstifikasi } \\
\text { baik }\end{array}$ & $9-10$ \\
\hline $\begin{array}{l}\text { Marmer dengan rekahan, gamping dan } \\
\text { dolomit terkarstifikasi sedang }\end{array}$ & $7-8$ \\
\hline Batu gamping dan dolomit bercelah & $5-6$ \\
\hline Pasir dan kerikil koluvial & 4 \\
\hline Napal, breksi dan konglomerat & 3 \\
\hline Batuan plutonik dan metamorf & 2 \\
\hline Skiss, slate dan lempung & 1 \\
\hline
\end{tabular}

Tabel 2. Klasifikasi dan skoring variabel zona infiltrasi

\begin{tabular}{|l|l|}
\hline \multicolumn{1}{|c|}{ Zona Infiltrasi } & \multicolumn{1}{c|}{ Skor } \\
\hline Zona infiltrasi utama & 10 \\
\hline Zona infiltrasi lain & 1 \\
\hline
\end{tabular}

Tabel 3. Klasifikasi dan skoring variabel tanah

\begin{tabular}{|l|l|}
\hline \multicolumn{1}{|c|}{ Tanah Skor } \\
\hline Litosols & 10 \\
\hline Albic Arenosols dan Calcic Xerosols & 9 \\
\hline $\begin{array}{l}\text { Rendzina, Calcareous Regosols dan } \\
\text { Fluvisols }\end{array}$ & 8 \\
\hline $\begin{array}{l}\text { Eutric dan Distric Regosols serta } \\
\text { Solonchaks }\end{array}$ & 7 \\
\hline Calcic Cambisols & 6 \\
\hline
\end{tabular}

\begin{tabular}{|l|l|}
\hline Eutric Cambisols & 5 \\
\hline $\begin{array}{l}\text { Eutric Histososla, Orthic dan Calcic } \\
\text { Luvisols }\end{array}$ & 4 \\
\hline Chromic Luvisols & 3 \\
\hline Planosols & 2 \\
\hline Cromic Vertisols & 1 \\
\hline
\end{tabular}

Tabel 4. Klasifikasi dan skoring vaeriabel ketinggian

\begin{tabular}{|l|l|}
\hline \multicolumn{1}{|c|}{ Ketinggian } & Skor \\
\hline$\leq 300$ mdpal & 1 \\
\hline$>300-600 \mathrm{mdpal}$ & 2 \\
\hline$>600-900 \mathrm{mdpal}$ & 3 \\
\hline$>900-1200 \mathrm{mdpal}$ & 4 \\
\hline$>1200-1500 \mathrm{mdpal}$ & 5 \\
\hline$>1500-1800 \mathrm{mdpal}$ & 6 \\
\hline$>1800-2100 \mathrm{mdpal}$ & 7 \\
\hline$>2100-2400 \mathrm{mdpal}$ & 8 \\
\hline$>2400-2700 \mathrm{mdpal}$ & 9 \\
\hline$>2700 \mathrm{mdpal}$ & 10 \\
\hline
\end{tabular}

Tabel 5. Klasifikasi dan skoring vaeriabel lereng

\begin{tabular}{|l|l|}
\hline \multicolumn{1}{|c|}{ Kemiringan Lereng } & Skor \\
\hline$\leq 3 \%$ & 10 \\
\hline$>3-8 \%$ & 9 \\
\hline$>8-16 \%$ & 8 \\
\hline$>16-21 \%$ & 7 \\
\hline$>21-31 \%$ & 5 \\
\hline$>31-46 \%$ & 4 \\
\hline$>46-76 \%$ & 3 \\
\hline$>76-100 \%$ & 2 \\
\hline$>100 \%$ & 1 \\
\hline
\end{tabular}

Hasil skoring kemudian ditumpangsusun (overlay) dengan menggunakan sistem informasi geografis (SIG). Tumpangsusun dilakukan dengan menggunakan rumus sebagai berikut:

$R=(A+P+3 L+2 I+S) / 0,9$ (Andreo dkk, 2008)

$$
\begin{aligned}
& \mathrm{R}=\text { Imbuhan airtanah dalam persen } \\
& \mathrm{A}=\text { Ketinggian } \\
& \mathrm{P}=\text { kemiringan Lereng } \\
& \mathrm{L}=\text { Litologi } \\
& \mathrm{I}=\text { Zona Infiltrasi } \\
& \mathrm{S}=\text { Tanah }
\end{aligned}
$$

Hasil tumpangsusun menggunakan sistem informasi geografis, kemudian diklasifikasikan dengan klasifikasi yang dibuat oleh Andreo, dkk (2004) sebagai berikut:

Tabel 6. Klasifikasi nilai imbuhan (R)

\begin{tabular}{|l|l|}
\hline Nilai Imbuhan $(\mathrm{R})$ & Kelas \\
\hline$\leq 20 \%$ & Sangat Rendah \\
\hline$>20-40 \%$ & Rendah \\
\hline$>40-60 \%$ & Sedang \\
\hline$>60-80 \%$ & Tinggi \\
\hline
\end{tabular}




\begin{tabular}{|l|l}
\hline$>80 \%$ & Sangat Tinggi \\
\hline
\end{tabular}

Tingkat imbuhan airtanah yang tinggi pada suatu wilayah akan menyebabkan tingkat kerentanan airtanah yang tinggi pula. Imbuhan airtanah yang tinggi pada suatu wilayah airtinya akan menyebabkan semakin mudahnya polutan atau kontaminan masuk ke dalam sistem airtanah, hal ini karena semakin banyak air yang masuk ke dalam sistem airtanah. Jumlah imbuhan airtanah dicerminkan oleh nilai imbuhan (R) yang merupakan jumlah persen dari hujan efektif pada suatu wilayah.

Peta ketinggian dan kemiringan lereng dihasilkan dari peta rupa bumi Indonesia (RBI) skala 1:25.000 terbitan BAKOSURTANAL. Data litologi diperoleh dari Peta Geologi Lembar Yogyakarta (1995) dan Lembar Surakarta (1992) skala 1:100.000 terbitan Pusat Penelitian dan Pengembangan Geologi serta survei lapangan untuk menghasilkan peta litologi pada skala 1:50.000. Peta zona infiltrasi dihasilkan dari peta rupa bumi Indonesia (RBI) skala 1:25.000 terbitan BAKOSURTANAL dan survey lapangan, sedangkan peta tanah dihasilkan dari peta tanah terbitan Pusat Penelitian Tanah dan Agroklimat (PUSLITANAK) Bogor skala:1:50.000 yang diubah dalam klasifikasi FAO.

\section{WILAYAH PENELITIAN}

Wilayah penelitian terletak di sebagian Kawasan Karst Gunungsewu yang meliputi Kecamatan Paliyan dan Kecamatan Saptosari, Kabupaten Gununungkidul, Propinsi Daerah Istimewa Yogyakarta.

\section{DISKUSI DAN PEMBAHASAN}

Litologi wilayah penelitian terdiri dari gamping terkarstifikasi baik, gamping terkarstifikasi sedang dan batuan napal. Batuan gamping terletak di bagian selatan yang memiliki topografi berbukit, sedangkan napal terletak pada Cekungan (Basin) Wonosari. Batuan gamping terkarstifikasi baik memiliki topografi berbukit dan diterbentuk beberapa dolin dan sinkhole. Batuan gamping terkarstifikasi sedang memiliki topografi yang relatif datar, sedangkan batuan napal memiliki topografi datar.

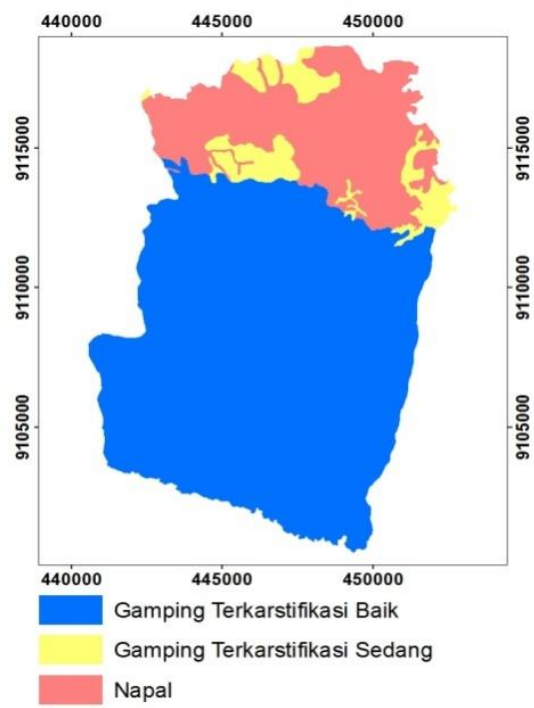

Gambar 1. Peta litologi wilayah penelitian

Zona infiltrasi dibagi menjadi dua, yaitu zona infiltrasi utama dan zona infiltrasi yang lain. Zona infiltrasi utama terletak di kawasan berbatuan gamping yang terkarstifikasi baik. Hidrologi permukaan dan airtanah dihubungkan oleh intensifnya infiltrasi melalui kekar, retakan dan lubang hasil pelarutan seperti sinkhole (luweng).

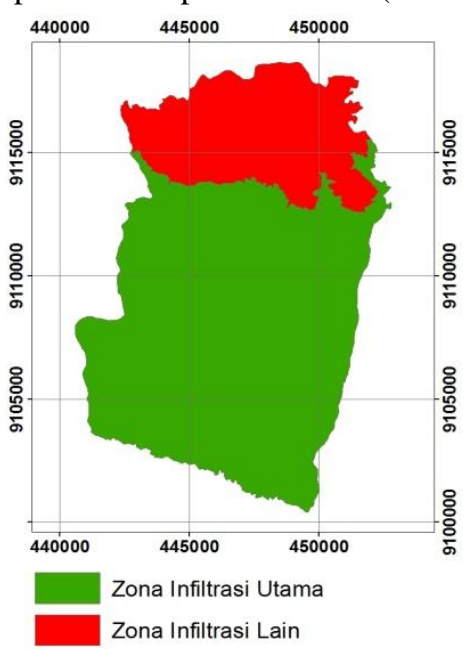

Gambar 2. Peta zona infiltrasi wilayah penelitian

Ketinggian wilayah penelitian berkisar antara 0 mdpal sampai dengan 600 mdpal. Wilayah terendah terletak di pantai selatan Kecamatan Saptosari, sedangkan wilayah tertinggi terletak di bagian tengah. Wilayah dengan ketinggian <300 mdpal merupakan bagian dari perbukitan karst terkarstifikasi baik dan Cekungan Wonosari, sedangkan wilayah dengan ketinggian 300-600 mdpal terletak di bagian utara dari perbukitan karst yang terkarstifikasi baik. 


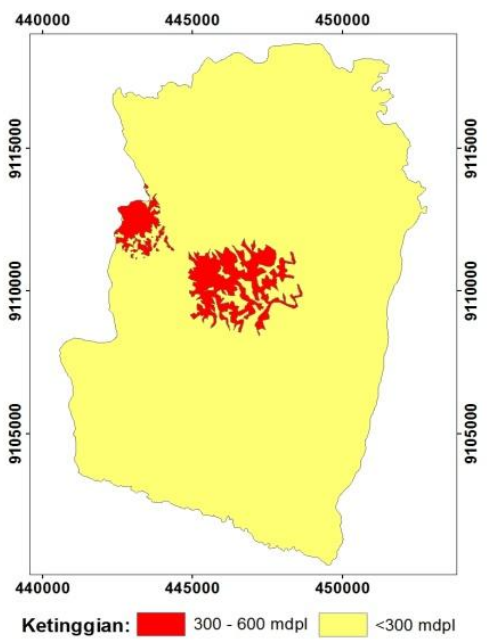

Gambar 3. Peta ketinggian wilayah penelitian

Klasifikasi tanah yang digunakan dalam metode APLIS adalah klasifikasi tanah dari Food and Agriculture Organization (FAO). Tanah pada wilayah penelitian terdiri dari Litosols, Cambisols, Distric Regosols, Calcareous Regosols dan Vertisols. Litosols dan Calcareous Regosols terdapat di wilayah berbatuan gamping terkarstifikasi baik, Distric Regosols dan Vertisols terdapat pada di Cekungan Wonosari, sedangkan Cambisols terdapat pada Cekungan Wonosari dan wilayah berbatuan gamping terkarstifikasi sedang ataupun terkarstifikasi baik.

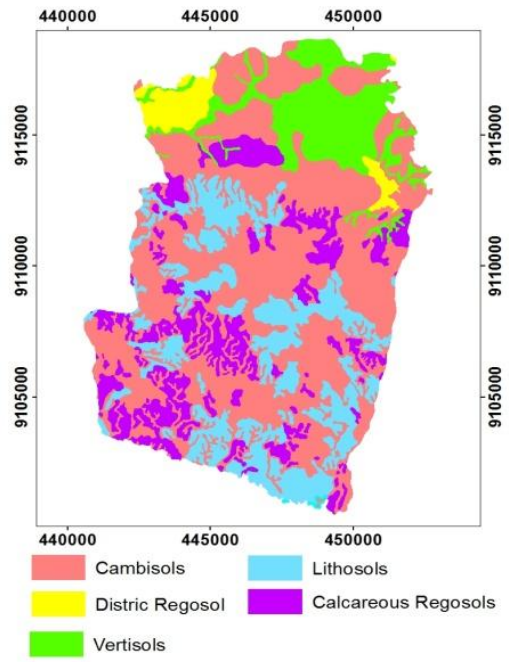

Gambar 4. Peta tanah wilayah penelitian

Kemiringan lereng pada wilayah penelitian berkisar antara $0 \%$ sampai dengan $46 \%$. Cekungan Wonosari didominasi dengan kemiringan 0\%-8\% yang berarti memiliki topografi yang datar, sedangkan perbukitan karst di bagian selatan memiliki kemiringan lereng dominan $8 \%-16 \%$ pada bukit-bukit karst dan 0\%-3\% pada dolin. Wilayah dengan kemiringan rendah akan memiliki kemampuan infiltrasi yang lebih besar karena air bergerak dengan lambat sehingga semakin banyak air yang dapat meresap menjadi airtanah.

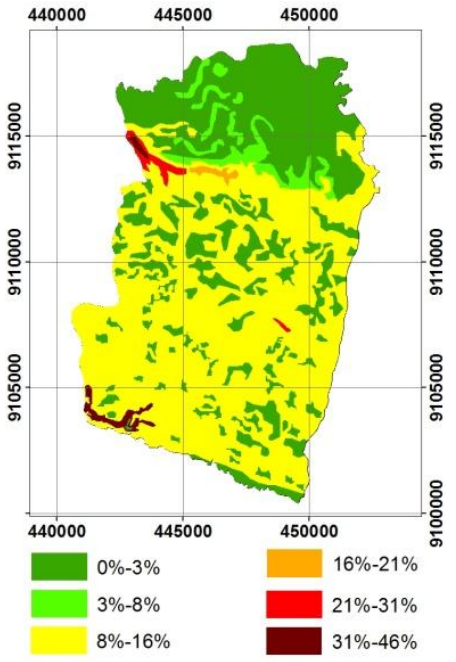

Gambar 5. Peta kemiringan lereng wilayah penelitian

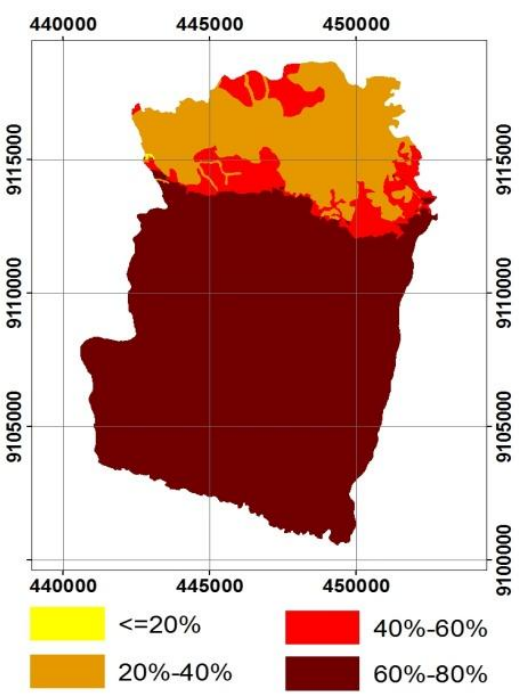

Gambar 6. Peta nilai imbuhan airtanah (R)

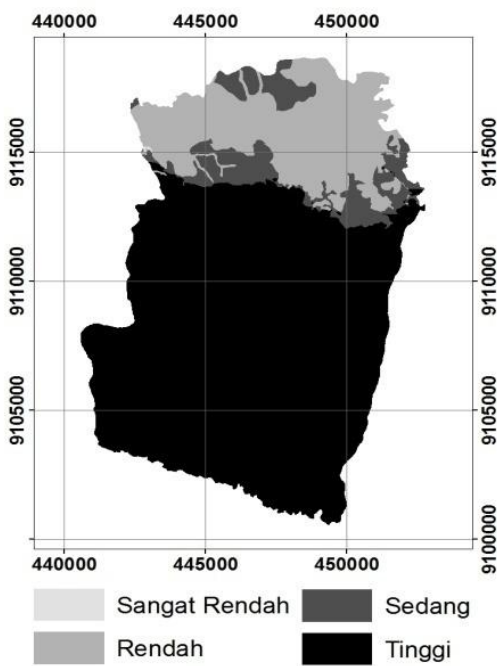

Gambar 7. Peta tingkat kerentanan airtanah 
Hasil analisis tumpangsusun menunjukkan bahwa nilai imbuhan airtanah di wilayah penelitian adalah antara $20 \%$ sampai dengan $80 \%$. Nilai ini menunjukkan imbuhan airtanah pada wilayah penelitian adalah antara $20 \%-80 \%$ dari total hujan efektif yang terjadi. Berdasarkan klasifikasi yang dibuat oleh Andreo, dkk (2008), wilayah ini memiliki imbuhan airtanah dengan klasifikasi sangat rendah sampai dengan tinggi. Imbuhan airtanah sangat rendah dan rendah terletak pada bagian utara wilayah penelitian yang merupakan bagian dari Cekungan Wonosari yang berbatuan napal. Imbuhan airtanah dengan klasifikasi sedang terdapat pada wilayah dengan batuan gamping terkarstifikasi sedang yang terletak pada zona peralihan Cekungan Wonosari dan perbukitan karst. Hasil tumpangsusun ini juga mencerminkan tingkat kerentanan airtanah pada wilayah penelitian. Hal ini berarti wilayah dengan batuan gamping terkarstifikasi baik memiliki kerentanan airtanah tinggi, wilayah dengan batuan gamping terkarstifikasi sedang memiliki tingkat kerentanan airtanah sedang, sedangkan wilayah dengan batuan napal memiliki tingkat kerentanan airtanah sangat rendah sampai rendah.

\section{PENUTUP}

\subsection{Kesimpulan}

Berdasarkan hasil penelitian yang dilakukan, maka dapat diambil kesimpulan bahwa wilayah penelitian memiliki imbuhan airtanah dengan klasifikasi sangat rendah sampai dengan tinggi. Imbuhan airtanah sangat rendah dan rendah terletak pada Cekungan Wonosari yang berbatuan napal. Imbuhan airtanah dengan klasifikasi sedang terdapat pada wilayah dengan batuan gamping terkarstifikasi sedang yang terletak pada zona peralihan Cekungan Wonosari dan perbukitan karst.

Hasil penelitian juga menghasilkan suatu kesimpulan bahwa tingkat kerentanan airtanah pada wilayah penelitian termasuk dalam tingkat kerentanan airtanah sangat rendah sampai dengan tingkat kerentanan airtanah tinggi. Wilayah dengan batuan gamping terkarstifikasi baik memiliki kerentanan airtanah tinggi, wilayah dengan batuan gamping terkarstifikasi sedang memiliki tingkat kerentanan airtanah sedang, sedangkan wilayah dengan batuan napal memiliki tingkat kerentanan airtanah sangat rendah sampai rendah.

\subsection{Saran}

Hal penting yang harus diperhatikan dalam analisis tumpangsusun (overlay) adalah bahwa peta yang ditumpangsusunkan memiliki skala yang sama. Hal ini jarang diperhatikan karena peta dasar yang tersedia dari beberapa instansi tidak semua memiliki skala yang sama, sehingga untuk melakukan tumpangsusun harus dibuat peta yang baru sesuai dengan skala yang dibutuhkan.

\section{PUSTAKA}

Adji, T. N. 2006. Peranan Geomorfologi dalam Kajian Kerentanan Air Bawah Tanah Karst. Gunung Sewu, Indonesian Cave and Karst Journal, 2(1). 68-79.

Andreo, B., Vías, J., Durán, J.J., Jiménez, P., LópezGeta, P. A., dan Carrasco, F. 2008. Methodology for Groundwater Recharge Assessment in Carbonate Aquifers: Application to Pilot Sites in Southern Spain. Hydrogeology Journal, 16. 911925.

Andreo, B., Carrasco, F., Durán, J. J., dan LaMoreaux, J. W. 2010. Advances in Research in Karst Media. Berlin: Springer-Verlag.

Asdak, C. 2007. Hidrologi dan Pengelolaan Daerah Aliran Sungai. Yogyakarta: Gadjah Mada University Press.

Ford, D. dan Williams, P. 1992. Karst Geomorphology and Hydrology. London: Chapman and Hall.

Harter, T. dan Walker, L. G. 2001. Assessing Vulnerability of Groundwater. California: California Department of Health Services.

IUSS Working Group WRB. 2007. World Reference Base for Soil Resources 2006, first update 2007: World Soil Resources Reports No. 103. Roma: FAO.

Lubis, F. R. 2006. Bagaimana Menentukan Daerah Resapan Air Tanah? Jurnal Inovasi, 6(18). 3235.

Piscopo, G. 2001. Groundwater Vulnerability Map Explanatory Notes. New South Wales: New South Wales Department of Land and Water Conservation.

Prastoro, R. A., Sunarto, dan Putra, D. P. E. 2009. Tingkat Risiko Pencemaran Airtanah Bebas oleh Senyawa Nitrat di Kabupaten Bantul Propinsi Daerah Istimewa Yogyakarta. Jurnal Kebencanaan Indonesia, 2(1). 419-442.

Seyhan, E. 1990. Dasar-dasar Hidrologi. Yogyakarta: Gadjah Mada University Press.

Veni, G. dan DuChene, H. 2001. Living With Karst: A Fragile Foundation. Alexandria: American Geological Institute.

Vrba, J. dan Zoporozec, A. 1994. Guidebook on Mapping Groundwater Vulnerability. Hannover: International Association of Hydrogeologist.

Worosuprojo, S. dkk. 1997. Kajian Ekosistem Karst di Kabupaten Gunungkidul Propinsi Daerah Istimewa Yogyakarta. Laporan Penelitian. Biro Bina Lingkungan Hidup Propinsi Daerah Istimewa Yogyakarta dan Fakultas Geografi Universitas Gadjah Mada.

Zwahlen, Francois. 2003. Vulnerability and Risk Mapping for the Protection of Carbonate (Karst) Aquifers. Luxembourg: EUROPEAN COMMISSION, Directorate-General XII Science, Research and Development. 